\title{
THE BIRTH OF INTERNATIONAL RELATIONS AS A SOCIAL SCIENCE: A COMPARED ANALYSIS OF THE ANGLO AMERICAN WORLD AND CONTINENTAL EUROPE
}

\section{Pedro Emanuel Mendes ${ }^{1}$}

\section{Introduction}

This paper develops a comparative contextualization of the birth of International Relations (IR) ${ }^{2}$ as an autonomous discipline in the Anglo-American $^{3}$ world and Continental Europe ${ }^{4}$. It presents a historiographical synthesis of the origin of IR and a balance of the main institutional and scientific frameworks of the American, English, Nordic, French and German cases.

Although the idea of a simplistic dichotomy between Western and non-Western thinking is currently in place - both in the academic and political realms - it is important to demonstrate that there is not only one Western thinking. In this context, starting from historical-contextual (Schmidt and Guilhot 20I9) and cultural-institutional (Jørgensen, Knudsen 2006,I0) approaches, this paper traces a broader picture of the invention of the IR discipline, demonstrating the diversity of institutional paths and theoretical-methodological identities of various Western academic communities.

Due to the current globalization and hybridization of IR, there is an

I PhD Researcher at IPRI-NOVA and Assistant Professor at the Faculty of Law of Lusíada Porto University (Faculdade de Direito da Universidade Lusíada Porto, FDULN).

2 In a traditional sense of view, we will use International Relations (IR) in uppercase to refer to the discipline and International Relations (ir) in lowercase to refer to empirical phenomena 3 The Anglo-American world is not just the US and the UK. It also includes Canada, Ireland, Australia, and New Zealand but due to article size limitations, we do not include them.

4 Continental IR is not limited to the cases presented. Due to article size limitations, we do not address, for example, the Central and Eastern European community, which is part of the Central and East European International Studies Association (CEESSA), which sponsors a relevant journal, the Journal of International Relations and Development, founded in I984 (37/85 JCR WOS). 
explosion of narratives and counter-narratives about when, how and why the IR discipline was invented (Smith I995; Kahler I997; Carvalho, Leira and Hobson, 20II; Schmidt 20I3; Buzan, Lawson 20I4 ). This debate has become even more complex with the need for the discipline to discuss non-Western thinking and to try to include other geocultural traditions in its theoretical discourse (Wæver, Tickner 2009; Acharya 20I4). Then there is the eternal debate about what IR is and what is its relationship (dependence, independence, interdependence) with Political Science (PS) and History. This discussion of the identity and history of IR puts institutional pressures and anxieties on the solidification of their academic autonomy (Wæver 2013). At the end of the day, these discussions are a positive fact, as they demonstrate their vitality and help to deconstruct the limitations of dominant canonical views by introducing new and plural debates into the history of the discipline's "great debates." However, it is not possible to discuss the identity of IR without having a solid knowledge of their main historical and institutional milestones.

In developing a comparative analysis on the birth of IR autonomy we aim to achieve two objectives. On the one hand, the article seeks to contribute to the dialogue on the social construction of IR and its historiography. On the other hand, the article seeks to illuminate the relationship between historical and academic contexts. In particular, highlight the simultaneous processes of academic integration and differentiation - theoretical and institutional - of the schools of the Anglo-American axis concerning the European semiperipheral schools of the cases under analysis. Although IR is a markedly western discipline (Hobson 20I2), it is important to realize that there are identitarian and cultural differences in the various academic communities that compose it. These differences are explained by the diversity of historical contexts and consequent reflexes in the academic and scientific contexts.

The article is organized into three parts. It begins by presenting the main contexts and political-academic frameworks of the birth and formation of the discipline, namely the importance of the American school in the affirmation of IR as an autonomous social science. Secondly, it addresses the European views on IR discipline, highlighting its most developed schools: the English school and the Nordic school. Finally, it presents a brief contextualization of the rediscovery and affirmation of IR in Continental Europe, underlining the main institutional and scientific frameworks of the French and German schools.

Its main argument is that to achieve a sophisticated understanding of the birth and development of academic disciplines, we must develop an interconnected analysis between historical-political contexts and academic-scientific contexts. Conscious of the limitations of an article to capture all the 
dimensions present at the birth of IR, this work is another contribution to the comparative study of the identity of the discipline and, above all, an invitation for current and future generations to assume the historical condition of IR and explore more and better the relationship between ideas and contexts.

\section{The Anglo-American Center of the World and the Invention of the Discipline: Dialectic between International Relations Policy and IR Science}

IR as an autonomous scientific discipline emerged in the early twentieth century in the United Kingdom and the US. Although in I859 the Chichele Chair of International Law and Diplomacy began in Oxford, where international phenomena were already being analyzed, it is possible to identify the birth of the discipline in the early years of the twentieth century. The publication in 1900 of Paul S. Reinsch's World Politics at the End of the Nineteenth Century was the first book written from the standpoint of an autonomous IR discipline (Olson, Groom I99I). Reinsch was a professor of political science at the University of Wisconsin and began teaching a course entitled "Contemporary International Politics" in I906 (Schmidt 2008). There is no unanimity about the first IR academic journal. Some point out that it was the International Conciliation, founded in I9Io and published by the Carnegie Endowment for International Peace (Olson and Groom I99I, 47-48). Others point out that the first IR Journal was the Journal of Race Development (I9IO), later designated the Journal of International Relations (I9I9), taking its final form in I922 as Foreign Affairs (Vitalis 2005).

From an institutional point of view, although the American Political Science Association (APSA) has existed since I9035, it was in I9I9 that the first IR chair at the University of Wales in Aberystwyth was born. At the same time in London and New York are born the Royal Institute of International Affairs (Chatham House) and the Council of Foreign Relations. Founded respectively in I920 and I92I, these private institutions aimed to promote the scientific study of international issues (Olson, Groom I991; Schmidt 2013).

5 The birth of APSA was an important milestone for the birth of IR, and can be assumed as one of its main origins (Schmidt I998; Viatlis 2005). By I920 the APSA already had I300 members, by 1940 it reached 2800 . In response to the discontent of APSA leadership and the need for affirmation of international studies, a group of internationalist scholars and practitioners founded the International Studies Association (ISA) in I958. Originally ISA was a regional association that ranged from 60 to two hundred members. Today, although headquartered in the US, is an international organization with over 6000 members, https:/www.isanet.org/ ISA/About-ISA/History. 
They are still two of the world's most influential Think Thanks today and the sponsors of two major academic journals, International Affairs and the Foreign Affairs $^{6}$. Then, in Geneva (IHES) 7 and London (LSE), the first IR research and teaching centers appear ${ }^{8}$. All of these early IR centers are closely related to the historical-political contexts of the time, notably the Grocian and liberal environment that encouraged the search for war solutions. Therefore, many of the academic-institutional leaders of this period have a close connection with the political world, such as diplomats, rulers or government advisers, or even as political leaders of pacifist movements.

However, it was in the US that the study of IR begins to strengthen and a new social science discipline was invented. Initially at the Universities of Chicago, South California (SIR), Columbia, Georgetown', Wisconsin, which were quickly followed by all major American universities, notably Harvard, Stanford, MIT, John Hopkins, Yale, Michigan, and Princeton ${ }^{\mathrm{IO}}$. It was at the University of Chicago that the Committee on International Relations began undergraduate studies in IR in I928. The University of Chicago was a pioneer school in the development of PS and IR and it was there that, from I943 Morgenthau (I948) wrote the fundamental works of Realism and tried to impose his vision against the American PS behaviorist revolution (Guillot, 2008; 20I7a). Chicago was also home to the liberal Quincy Wright, author of the seminal study, Study of War (I942), as well as The Study of International Relations (I955), where he advocates IR autonomy, but also underlines its interdisciplinary character, in particular in relation to geography and psychology.

Although the discipline took its first steps in the first decades of the century. In the twentieth century, it is from the new postwar international or-

6 Founded in I922, they are ranked 8th in WOS JCR respectively. Although both policy-oriented, Foreign Affairs, despite its scientific rigor and unmatched impact and dissemination, is not a peer-reviewed journal, unlike International Affairs.

7 The institute (universitaire) of hautes études internationales was founded in 1927 and was the first school exclusively dedicated to studying IR, it was also one of the first schools to offer a doctorate in IR. http://graduateinstitute.ch/home/about-us/discover-the-institute. html

8 In I924 the LSE began teaching IR under the responsibility of the Sir Ernest Cassel Chair of International Relations under Philip Noel-Baker. In I927 the current IR department is created, which in 1936 receives the Montague Burton Professorship of International Relations Chair, which had already been established in I930 in Oxford (Bauer, Brighi 2003).

9 The Edmund A. Walsh School of Foreign Service was founded in I9I9, the first policy school. Io This is a selection with criteria of historical relevance but is not exhaustive. There were other universities that played an important role at the beginning of the IR study but, but due to article size limitations, are not included. For example, Tufts University's Fletcher School of Law and Diplomacy is established in I933 and is one of the oldest schools to teach IR. 
der that the simultaneous development of the political and scientific hegemony of the United States is being developed. It was in the USA that IR gains the contours of autonomous academic scientific discipline, although assumed as an integral part of the PS and Government departments.

Even today the perennial question about whether IR is an autonomous discipline, a sub-discipline of PS, or an inter-discipline (Olson, Onuf I985, 4) is debatable. This debate, still useful for stimulating controversy, has become outdated by the assumption of IR autonomy. However, the progressive autonomy of the IR discipline does not mean a denial of its natural connection to PC or its interdisciplinary character. The issue of specialization and disciplinary hybridization is a general phenomenon in all disciplines in contemporary science, understanding this is as natural as understanding the existence of disciplinary boundaries.

Due to the exceptional postwar American political and intellectual environment, a rapid theoretical and institutional consolidation of the teaching and research of political and government studies was possible. This context, coupled with the need for the US to produce useful knowledge in shaping its foreign policy, has made IR a central field of study. As Stanley Hoffman ${ }^{\text {II }}$ (I977) has noted, IR in their theoretical and institutional origin were an "American social science." It was here that the IR came of age and the main stages where the great debates that built the discipline's identity took place were the universities and Journals in the US.

This does not mean that there were no major European, mainly Anglo-Saxon and Nordic, contributions throughout their major disciplinary debates: idealism / realism; traditionalism / scientism; pluralism-marxism / neoliberalism / neorealism; dominant theories / critiques / normative-positivism / post-positivism; rationalism / constructivism. For example, it is not possible to analyze the critical dissent and rise of constructivism and sociological approaches at the turn of the century without the participation of European IR. However, from a historical perspective, IR was dominated by US scholars. While there are exceptions from the UK and English School, Raymond Aron, and leading Canadian, Nordic, and Australian authors, the rule was that IR was a North American discipline during the twentieth century.

It is therefore unanimous that the discipline developed with an academic divide between the American Core and all other communities (Holsti I985; Wever I998; Friedrichs 2004; Wemheuer-Vogelaar et al 20I6; Maliniak et al 20I8). This division is sometimes assumed, subjectively, as negative.

II Stanley Hoffman was born in Austria and lived and studied in France (Science PO, Paris), a French citizen and Jewish refugee. He became an important US RI academic at Harvard, where he founded the Center for European Studies in I968. 
This is not our case. Although aware of the limitations of any hegemonic domain, in science, as in politics, hegemony is a condition based on objective capabilities. As is demonstrable, the American domain of scientific production in IR is no different from the American domain of scientific production in other social sciences (Kristensen 20I3). While it is possible to see a relative parochialism of US domination in IR (Biersteker 2009), we should not over-flush its shortcomings or diminish its qualities. Without the American scientific world there would hardly be an IR discipline. However, in this process, we must also not overlook the intellectual role of European emigrant academics. Many of the greatest academic talents of the formative years of the discipline, such as John Herz, Karl Deutsh, Ernest Haas, and Morgenthau, came from continental Europe to the US fled from Nazism. This scientific migratory cycle was one of the key elements for the rapid affirmation of the US academic and scientific world, not only in PS / IR but in all other social and non-social science disciplines.

The consequences of World War II were also devastating for academic life in continental Europe, where more than a decade was lost. Most of the top social scientists in northern Europe have resumed their careers in the US. This generation of exiles even originated the creation of a new school, the New School for Social Research in New York. All major American universities had at least one European professor in exile at their social science faculties. Inescapable scholars such as Paul Lazarsfeld, Kurt Lewin, Wolfgang Kholer, Hans Spier, Leo Lowenthal, Leo Strauss, Franz Neuman, Henry Ehrman, Otto Kirchheimer, Herbert Marcuse, and others have been instrumental in US academic excellence. On the other hand, while modern PS indeed made its most significant advances in the US after World War II, let us not forget that the founders of American PS - Woodrow Wilson, Frank Goodnows, Charles Merrian - obtained their degrees or postgraduates studies in Europe, mainly in Germany (Almond i998).

This means that we should tint the idea that IR is just an American invention. From an intellectual point of view, IR are as much or more European than American. What happened is that in the USA there were material, institutional and ideational conditions that allowed the rapid development of political studies and in particular of IR. As in other fields, the US has presented innovative opportunities for academic project development without the corporate and funding constraints in Europe. Especially at this time, the US lived a true enlightenment period that propitiated a unique development of Political Science and where the ideas of European emigrant academics were decisive.

Although not overwhelmingly, as happened in the formative years of 
the discipline, it is possible to see the continuity of US academic hegemony. In the most relevant schools, Journals, and academics, even today the brightest stars ${ }^{\mathrm{I2}}$ are North American. This does not mean that there are no such or shimmering stars outside the US, but as a rule, to shine and achieve academic stardom the most effective way is to step on the American stage.

Although imperfect and debatable, studies of IR rankings give us a clear picture of this hegemony. As a rule, in the Top ro of the first cycle are: Harvard, Princeton, Stanford, Columbia, Georgetown, Yale, Chicago, Dartmouth, George Washington, and American. In the second cycle are: Georgetown, John Hopkins, Harvard, Princeton, Tufts , Columbia, George Washington, American, LSE, Chicago. In the third cycle are: Harvard, Princeton, Stanford, Columbia, Yale, Chicago, UCSD, C. Berkley, Michigan, MIT. In the top ro of the journals we have, as a rule, seven American journals, two English and one European, often on par with the Nordic ones. This reflects well the relative importance of their academic communities. However, the European journal, European Journal International of International Relations (1995) ${ }^{13}$ was the one that most affirmed itself in relative terms. Another recent Journal that stands out for its progressive affirmation is International Political Sociology (2007), which was a project that also had an important European contribution. Another example that demonstrates the development of IR in Europe is the statement of the Journal of International Relations and Development, which went from Q4 at Scopus SJR in I999 to QI in 2017.

Despite their relative variability, as a rule, all studies show that by combining citation impact with reputational impact ${ }^{\mathrm{I}}$, journals that consistently rank first are Anglo-American and Nordic. (Breuning, Bredehoft and Walton 2005; Giles, Garand 2007; Maliniak et al 2012, 2014) $)^{15}$. First, we have the

I2 Today, as in the past, many leading scholars are not originally American, but their careers and founding works were born in the US, so they are considered American scholars.

I3 This Journal was originally sponsored by the Standing Group on International Relations (SGIR) of the European Consortium for Political Research (EPCR). There is currently a joint sponsorship of SGIR and the European International Studies Association.

I4 The impact factor is relevant for hard and natural sciences. In social and human sciences it is more debatable. The quantitative "fever" of metrics, citations and rankings does not necessarily reflect the quality and innovation of published articles, often having perverse effects. However, they are a useful element of analysis. One of the reputational factors is the age of the Journals. As a rule, top journals were established before I990. Exceptions that confirm the rule are, for example, the International Studies Review (I994) or the Security Studies (I99I), but still they date back further on. In the 2Ist century there was a boost in IR that reflects the global diffusion of the discipline, as well as the industrialization of the scientific market.

I5 According to TRIP (Maliniak et al 20I2) the twenty most influential journals are: I. International Organization; 2.International Studies Quarterly; 3.International Security; 4.Foreign Affairs; 5.APSR; 6. World Politics; 7.European Journal of International Relations; 8.Journal of 
North American: International Organization; International Security; World Politics; International Studies Quarterly; the most comprehensive American Political Science Review and American Journal of Political Science; and the Journal of Conflit Resolution. Then comes the European Journal of International Relations and the English Review of International Studies and Millennium, to which we have to add the Nordic. Strictly speaking, the Nordic Journal of Peace Research; Cooperation and Conflict and Security Dialogue are often above English, and even US, at the impact factor level ${ }^{\mathrm{I} 6}$.

If we increase to a top 20 the difference is blurred. If we consider the post-I990 emergency and the affirmation of new journals, then Europe, along with other continents, can balance and even surpass the US. This confirms two trends. First, the traditional US domain. Second, the global emergence of IR, notably its growing affirmation in continental Europe. This phenomenon is not limited to Europe. Globally there is a movement of institutional and scientific solidification of the study of IR. Especially in Latin America ${ }^{17}$, notably Brazil ${ }^{18}$, and Asia, where the highlight goes to India ${ }^{19}$ and China ${ }^{20}$.

Conflict Resolution; 9.Foreign Policy; ro.Review of International Studies; Ir.Millennium: Journal of International Studies; I2.AJPS; I3.International Affairs; I4.Security Studies; I5.Review of International Political Economy; I6. Journal of Peace Research; I7. International Studies Review; I8.International Relations; I9.Comparative Politics; 20.Global Governance.

I6 Based on the JCR, International Relations, 20I7 Web of Science (WOS), Social Science Citations Index (SSCI) (http://mil.clarivate.com/cgi-bin/jrnlst/jlsubcatg.cgi?PC=SS)

I7 According to the Scopus 2017 SJR which includes 466 PS and IR Journals (https://www. scimagojr.com/journalrank.php?area=3300\&category=3320) we can highlight PUC's Revista de Ciencia Politica (I66), Santiago de Chile, CIDE's Politica y Gobierno (I99), Mexico (which are part of the WOS Social Sciences Citation Index (SSCI) and JCR) and Colombia International (256), of the University of the Andes.

I8 As a rule, major Brazilian universities have undergraduate and postgraduate degrees in IR. There are about thirteen IR academic journals in Brazil. The journals that make up the Scopus SJR (20I7) in PS / IR are: Austral (266); the Revista Brasileira de Politica Internacional (298) and Estudos Internacionais. However, RBPI is the only one that integrates the WOS SSCI and JCR and, according to TRIP, the most relevant Journal for the Brazilian IR community. Without being exhaustive, but trying to overcome the limitations (commercial and quantitative) of ranking marketing, it is necessary to introduce qualitative rigor. Thus, by associating the impact factor with the reputational factor, it is possible to highlight, for example, the Contexto Internacional of PUCRio and the Brazilian Journal of International Relations of UNESP, two journals not indexed by Scopus, but from two major universities. Then it is necessary to integrate other interdisciplinary journals that publish IR articles. Some of the most relevant are the Revista Sociologia e Politica; the Opinião Pública; the Dados; the Lua Nova; the Brazilian Political Science Review; or the Revista Brasileira de Ciência Política. On the Brazilian IR community and its relative perception of American hegemony see Villa, and Pimenta (20I7); on the production of national concepts see Cervo (2008). I9 Some of the most relevant IR Journals in India are the Jadavpur Journal of International Relations; India Quarterly and International Studies.

20 China exhibits extraordinary developments, with Chinese scholars publishing in leading 
Although rankings are mainly quantitative aggregate data that do not accurately reflect the quality of teaching and research, particularly about smaller schools, they serve as indicators for the Anglo-American mastery of the subject. Thus, on average, the Anglo-American university world represents $77 \%$ of the Top 25 , and from this the US represents $70 \%$.

Table 1. Ranking Universities in PS / IR

\begin{tabular}{|l|l|}
\hline op 25, 20I8 QS WUR & Top 25, 2018, THE WUR ${ }^{\text {20 }}$ \\
\hline I Harvard & I Oxford \\
\hline 2 Oxford & 2 Harvard \\
\hline 3 Princeton & 2 MIT \\
\hline 4 Sciences Po & 4 Stanford \\
\hline $\begin{array}{l}\text { 5 London School of Econom- } \\
\text { ics and Political Science (LSE) }\end{array}$ & 5 Princeton \\
\hline 6 Cambridge & 6 Cambridge \\
\hline 7 Yale & 7 Chicago \\
\hline $\begin{array}{l}\text { 8 Australian National Univer- } \\
\text { sity (ANU) }\end{array}$ & 8 Yale \\
\hline 9 California, Berkeley & 9 Michigan \\
\hline Io Columbia & I0 LSE \\
\hline II Georgetown & II California, Berkeley \\
\hline $\begin{array}{l}\text { I2 National University of Sin- } \\
\text { gapore (NUS) }\end{array}$ & I2 Columbia \\
\hline I3 Chicago & I3 Pennsylvania \\
\hline I4 Toronto & I4.LSE \\
\hline I5 Tokyo & I5 California, Los Angeles \\
\hline
\end{tabular}

journals. China's rise is central to IR as it is the only individual actor capable of mitigating US hegemony. Its major institutional milestone is the relevance of its flagship journal: the Chinese Journal of International Politics, which ranks 22th in the WOS SSCI JCR ranking in IR (85 journals).

2I QS World University rankings (Politics \& International Studies) Available at: https://www. topuniversities.com/university-rankings/university-subject-rankings/20I8/politics

22 Times Higher Education World University Rankings, 2018 (politics and international studies). Available at: https://www.timeshighereducation.com/world-university-rankings/2018/subjectranking/socialsciences\#!/page/o/length/25/subjects/3090/sort_by/rank/sort_order/asc/ cols/stats 


\begin{tabular}{|l|l|}
\hline $\begin{array}{l}\text { I6 Massachusetts Institute of } \\
\text { Technology (MIT), EUA }\end{array}$ & I6 Cornell \\
\hline I7 Stanford & I7 UCLondon \\
\hline =I8 Sydney & I8 Wisconsin-Madison \\
\hline =I8 California, Los Angeles & I9 New York \\
\hline 20 Freie Universitaet Berlin & 20 Amsterdam \\
\hline 21 California, San Diego & 2I NUS \\
\hline 22 Johns Hopkins & 22 Peking \\
\hline 23 SOAS, London & 23 ANU \\
\hline$=24$ George Washington & 23 ETH Zurich \\
\hline$=24$ Hong Kong & 25 Northwestern \\
\hline
\end{tabular}

This domain is, even more, overwhelming in the opinion of IR experts and scholars, as shown below. Of course, the surveys are also a product of the Anglo-American world and most likely if they were conducted and published by a European Journal the results would be different, but not completely.

\section{Table 2. Top 25 IR Graduate Programs}

\begin{tabular}{|c|c|}
\hline Master in Public Policy Careers $^{\mathbf{2 1}}$ & Doctorates for academic careers $^{\mathbf{2 2}}$ \\
\hline I.Georgetown & I.Harvard \\
\hline 2.Harvard & 2.Princeton \\
\hline 3.Johns Hopkins & 3.Stanford \\
\hline 4.Princeton & 4.Columbia \\
\hline 5.Columbia & 5.Chicago \\
\hline 6.Tufts & 6.Yale \\
\hline 7.George Washington & 7.California, San Diego \\
\hline 8.American & 8.MIT \\
\hline 9.LSE & 9. Michigan \\
\hline Io.Chicago & Io.California, Berkeley \\
\hline
\end{tabular}

23 “Top Master's Programs for Policy Career in International Relations” Available at: https:// foreignpolicy.com/2018/02/20/top-fifty-schools-international-relations-foreign-policy/. Access I2 june 2018.

24 "Ph.D. Programs for Academic Career in International Relations". Available at: https:// foreignpolicy.com/2018/02/20/top-fifty-schools-international-relations-foreign-policy/. ccess I3 june 2018 . 


\begin{tabular}{|l|l|}
\hline II.Stanford & II.Georgetown \\
\hline I2.Oxford & I2 Oxford \\
\hline I3.Yale & I3.Cornell \\
\hline I4. Denver & I4.LSE \\
\hline I5.California, San Diego & I5. Ohio State \\
\hline I6.Syracuse & I6.Johns Hopkins \\
\hline I7.Cambridge & I7.George Washington \\
\hline I8.MIT & I8.Cambridge \\
\hline I8.Michigan & I9.American \\
\hline 20.California, Berkeley & 20.Duke \\
\hline 20.Pittsburgh & 2I.New York \\
\hline 22.New York & 22.Tufts \\
\hline 22.Sciences Po & 22.Minnesota \\
\hline 24.Duke & 24. Wisconsin, Madison \\
\hline 25. SOAS & 25.California, Los Angeles \\
\hline
\end{tabular}

\section{Table 3. Key US Institutional and Scientific Milestones}

\begin{tabular}{|l|l|}
\hline Major Institucional Milestones & IR Journals, (Index JCR, WOS, 20I7) \\
\hline American Political Science Association & American Political Science Review I906 \\
I903 & Foreign Affairs I922 (4) \\
Ist Foreign Policy School, Georgetown & International Organization I947 (I) \\
I9I9 & World Politics I948 (6) \\
Council of Foreign Relations I92I & American Journal of Political Science \\
Ist Study cicle, Chicago I928 & I956 International Studies Quarterly \\
International Studies Association I958 & I957 (I7) \\
& Journal of Conflict Resolution I957 (5) \\
& Ethics \& International Affairs I958 (50) \\
& International Security I976 (2) \\
& International Studies Review I994 (28) \\
& International Studies Prescpectives \\
& 2000 (5I) \\
& International Theory 2009 (26) \\
\hline
\end{tabular}

Source: Own elaboration based on the cited rankings. 


\section{International Relations in Europe, the other center}

\section{The United Kingdom and the English School}

The United Kingdom (UK) played a significant role in the early years of institutionalization of the discipline. Alongside the US, it was in the UK that IR was more and better institutionalized. In the US the rule was that IR specialize as an integrated discipline in PS, with neopositivist methodological concerns and a strong rationalist and neoeconomic influence. In the UK, IR were developing relatively more autonomously. Although with natural links to PS, the most distinctive influence of IR in the UK is their greatest interpretative-historicist concern, their methodological pluralism, and their particular connection to history and political theory.

Compared to the US, the English School (ES) has less concern with the formalization of inferential relationships and the construction of neopositivist models of behaviorist and economic influence. The great difference between IR in the US and the UK can be summarized in the dominant existence of a tendentially deductive, nomological, and empiricist approach by the American school, in contrast to the existence of a more interpretive and critical approach to positivist empiricism. part of the ES.

Next to the US, the English school, in a broad sense, is the largest network of IR scholars and has a major influence on the global marketplace for the subject's ideas. The greatest proof of this influence was the ability of English scholars to make IS one of the main IR theories. This capability has had its corollary in establishing a section on ES at the International Studies Association (ISA). In the words of its promoters, the rationale for this section is: "The English school is widely recognized as one of the main theoretical traditions in the study of IR. The North American component of the worldwide English school community is substantial, and section status within ISA would consolidate its place in the global network." 25

We cannot disconnect ES promoters' efforts from their instrumental affirmation strategy to diminish US hegemony in the discipline. On the other hand, and in parallel, there has been a strategy of trying to create more and better bridges between the English school and the Continental IR to precisely bridge the imbalance between the two sides of the Atlantic. As always, there are both positive and negative aspects of these strategies.

Due to article size limitations, we will not further develop our methodical position of doubt as to whether ES is a major theory of IR, with its research

25 Available at: www.polis.leeds.ac.ik/assets/files/.../english-school/isasection.pdf. 
program and a set of unique and independent paradigmatic axioms. We can, however, cast some clarifying questions on our position. Is ES possible to be a major theory when it is relatively easy to identify realists, idealists, neo-marxists, critics, liberals and constructivists? Can ES unambiguously be considered a theoretical paradigm of IR when it is itself embedded in theoretical paradigms?

However, this does not mean capitis diminutio for ES's theoretical arguments (Mendes 2019). Quite the contrary. At a time when paradigmatic wars are to be abandoned, the radicalism of the isms (Lake 20II) is challenged and a greater theoretical-paradigmatic eclecticism is proposed, the ES emerges as a theoretical castle-ideal refuge to escape paradigmatic battles and practice a kind of holistic theoretical eclecticism.

But what is ES anyway? In its strictest sense, ES concerns a group of theorists and practitioners who founded the British Committee on the Theory of International Politics (BCTIP) in January I959 and who, in parallel, developed their pedagogical and scientific work around the IR Department of the London School of Economics and Political Science (LSE), Chatham House, and the University of Cambridge (Vigezzi 2005). There are two main ES periods (Dunne I998). The first is that of his creation and production of his classic works (I950-I980) and where Charles Manning, Herbert Butterfield, Martin Wight, Hedley Bull, Adam Watson and RJ Vincent predominate. The second, from the nineties, is the post-classical period and its most striking authors are Barry Buzan, Andrew Hurrel, Robert Jakcson, Edward Kenne, Andrew Linkater, Richard Little, James Mayall, Hidemi Suganami, Nicholas J. Wheller Once again it is clear that questions like: is EH Carr not part of ES? And isn't Linklater a striking figure of critical theories? And aren't the classic Northedge and Evan Luard, or the contemporary Steve Smith part of ES? And aren't your critics (Roy Jones I98I) part of the ES?

Apparently no. That is why we can say that, in reality, IS in the strict sense is linked to a group of scholars who have produced outstanding works within the BCTIP and have become unavoidable works of a classical, traditional, interpretative and normative approach to IR theory. Although they overlap, we should not merge IS as a theoretical approach, of English school as a set of academics and their institutions. For example, the British International Studies Association (BISA) was born with another logic in I973. Although it was also an institutional instrument for promoting the ES. The oldest British association is The Political Studies Association (PSA), which began in I959 following IPSA and which, like the latter, received initial support from AACP and UNESCO.

The English school means, on the one hand, the locus of formation and construction of a rich and peculiar academic culture, the United Kingdom, namely of the best and oldest universities to study the political phenomena, especially Oxford, Cambridge and the LSE. On the other hand, the ES is 
a theoretical approach to the study of international relations which, although Anglo-Saxon, is distinct from the US dominant school and yet also different, because more sophisticated, from the continental European schools that originally thought the state, power and international relations based on realpolitik and traditional diplomatic history.

Although originated from authors with a significant epistemological and methodological variety among themselves, the English way of thinking and investigating international relations was surviving its founders and resisting the progressive Americanization of the discipline. Recently we have witnessed a resurgence of its importance and theoretical identity to such an extent that in sec. XXI, no IR Theories manual does not identify it as one of its main theories.

In a synthesis effort we can say that the fundamental concepts for the ES are Order, International Society, and the relationship between norms and anarchy. From a theoretical-paradigmatic point of view, ES places particular emphasis on the importance of the historical interpretation of the evolution of international society, its characterization and juridical-normative construction and, finally, the philosophical questioning about the balance between national power and cosmopolitan ethics in international relations (Linklater, Suganami 2006).

From a meta-theoretical point of view the ES occupies a place that can be situated in the middle space between a rationalist-positivist position and a reflexivist-postpositivist position. Today, leading English scholars emphasize the need for ES to make an effort to establish greater theoretical coherence, especially in terms of its epistemology and ontology (Buzan 2004, 200I). If so, IS has the potential to assert itself as a major theory and a true middle way between reflexivist and rationalist theories. The main arguments that are presented for this potential of theoretical affirmation lie in the importance of the central concepts developed by the ES.

Firstly, Martin Wight's (I99I) idea of the three theoretical traditions on the interpretation of international relations - realism, rationalism, revolutionism - allows an approach that encompasses various perspectives on international relations, which emphasizes the holistic and integrative nature of the ES. Secondly, despite the debate between conservative pluralist and progressive solidarity's theories (Wheeler I992), the ontological assumption of the existence of an International Society - and the neo-grocian nature of international relations - was, and remains, one of the most interesting and innovative thinking about international relations. Second, its non-positivist and contestatory character of the American rationalist / positivist dominant view has always allowed the ES to develop a more interpretive approach and to build bridges of dialogue with classic, normative, constructivist and critical approaches.

However, the ES major contribution to the progress of the discipline was the development of a theoretical vision capable of integrating history and 
philosophy into a political theory of international society. This originality led Brown (2000) to remember that if International Relations is an American social science, then International Political Theory is an English social science.

Table 4. Key UK Institutional and Scientific Milestones

\begin{tabular}{|l|l|}
\hline Major Institutional Milestones & IR Journals, (Index JCR, WOS, 20I7) \\
\hline I $^{\text {st }}$ Studies Cycle, Aberystwyth I9I9, LSE & International Affairs I922 (8) \\
I924 & Political Studies I953 (53) \\
Royal Institue of International I920 & International Relations I957 (43) \\
British Committee on the Theory of & International Politics I964 (62) \\
International Politics I959 & Millennium I97I (33) \\
The Political Studies Association I959 & Review of International Studies I975 \\
British International Studies Association & (20) \\
I973 & Cambridge Review International Affairs \\
& I986(68) \\
& British journal of Politics and IR I999 \\
& (3I) \\
\hline
\end{tabular}

Source: Own elaboration based on the cited rankings.

\section{The Nordic School}

Among the various geocultural traditions of IR in Continental Europe is one that stands out: the Nordic school. We can say that the Nordic school is the only one that has an internationally recognized identity, even by the Anglo-American center of discipline. This feature cannot be detached from time and the way IR was established in Scandinavia. Here IR discipline, especially the field of peace research, was established earlier than in most other continental Europe. This school consists of a regional cooperation network with major centers in Sweden, Denmark, Norway and Finland. From an institutional point of view, this cooperation is led by the Nordic Political Science Association (NOPSA) and the Nordic International Studies Association (NISA).

The origin of the Nordic school dates back to the mid-fifties and its first major institutional framework was the Peace Research Institute which was born in Oslo in I959 under Galtung's leadership. Following this, and with its sponsorship, the Journal of Peace Research emerged in 1964. Another relevant institutional framework is located in Copenhagen and is associated with the Copenhagen Peace Research Institute founded in 1985 and integrated from 2003 into the current Danish Institute of International Studies. It was here that the Copenhagen School on security studies was consolidated. There are also several other relevant IR centers from which we can highlight Lund University, 
Oslo University Center for European Studies (ARENA), Copenhagen University, Aarhus, Stockholm and Helsinki; the Norwegian Institute of International Affairs (NUPI), or the Upsala University to which Walter Carlsnaes, founding editor of the European Journal International Report (EJIR) and co-editor of the SAGE Handbook of International Relations, is attached.

The Nordic school has always had direct and indirect links with the American school. The best example is the brothers K. Holsti and O. Holsti who are relevant Anglo-American scholars, although of Finnish origin. After Americana (1903) and Canadiana (I9I3) the Finnish Political Science Association is the oldest (I936) and at the beginning of the institutionalization of the PS in Europe, the Nordics were always present, as demonstrated by the birth of the International Association. of Political Science (IPSA) in I949 (Boncourt 2009).

Although the Nordic singularity may in some respects show signs of erosion (Browning 2007), the Nordic IR school is an accomplished example of this singularity. This school is the result of an interesting fusion between the Anglo-Saxon world and a particular geocultural phenomenological approach. Its great distinctive innovation vis-à-vis the American school was to relativize the role of material power in IR. Unlike the neo-economic and rationalist dominant school of structural realism, the Nordic school did not naturalize anarchy and hierarchical relations of material power, and attempted a more sociological analysis of international relations. The Nordic school has not only focused on the political processes of the great powers in international politics and has given prominence to domestic politics and sub-national actors (Jönsson I993). Based on this epistemological option and its historical identity and culture, the Nordic school has developed a sophisticated Foreign Policy Analysis (Weaver I994; Carlsnaes I993, I994; Gustavsson I999; Jørgensen 2015; Mellander, Mouritzen 20I6). In this context, the Nordic school was decisive for the development of an EPA on the European Union (Larsen 2009; Jørgensen et. Al. 20I5).

In the Nordic countries IR has always been assumed as an important and autonomous discipline with a strong international component. This is why there are important university centers in the Nordic countries and journals with a relevant international circulation are published. The Nordic school is a good example of how, through regional cooperation, it is possible to simultaneously and interconnectedly develop nationally and internationally a theoretical and institutional identity with a global impact on IR discipline. Thus, the success of the Nordic multilevel cooperation model (national, regional, European and transatlantic) can be a model for all IR semiperipheral communities (Friedrichs 2006; 2004). Finally, it should be recalled that it was the Nordics who first stressed the need to develop an IR Eurodiscipline (Apunen I993). 
Table 5. Key Institutional and Scientific Milestones of the Nordic School

\begin{tabular}{|l|l|}
\hline Major Institutional Milestones & IR Journals, (Index JCR, WOS, 20I7) \\
\hline Peace Research Institute Oslo (PRIO) & Journal of Peace Research I964 (I5) \\
I959 & Cooperation and Conflict I965 (I4) \\
Norwegian Institute of International & Scandinavian Political Studies I966 \\
Affairs (NUPI) I959 & Security Dialogue I970 (9) \\
Nordic Political Science Association I975 & Internasjonal Politikk (85) \\
Copenhagen Peace Research Institute & \\
I985; Danish Institute of International & \\
Studies, 2003 & \\
Nordic International Studies Association & \\
I99I & \\
\hline
\end{tabular}

Source: Own elaboration based on the cited rankings.

\section{From the periphery of the formative years of IR to the rediscovery and affirmation of Continental IR: the cases of France and Germany}

\section{The French school}

In continental Europe, there have always been important academic and political thinking centers that have continued to study international relations. However, continental approaches to international relations have always been done through other disciplines, namely history, international law or sociology, without much concern for their autonomy, as IR was assumed as a non-autonomous multidisciplinary field of study. . International relations were an object of study and not a particular ontological and disciplinary methodology ${ }^{26}$.

In France, it is possible to identify the beginning of the institutionalization of Sciences Politiques in I871, with the creation of the École Libre des Sciences Politiques. In Belgium, in I892, the Ecole des Sciences Politiques et Sociales was founded at the Catholic University of Louvain (Giesen 2006). The first scientific center to be born in France is the Center d'études de politique étrangère (CEPE), which was created in I935, in the image of the Royal Institute of International Affairs of London with which it establishes relations. At this stage, there is cooperation between these organizations and the SDN Institute

26 This view was striking in the birth of IR in Portugal and even today French continental influences persist in understanding what IR is. Even today, both in France and in other non-theoretical communities, sometimes international relations tend to be confused with international journalism, that is, with the simple empirical description of facts (Mendes 20I2, 20I4). 
for Intellectual Cooperation (Guillot 20I7b). Which again proves that the IR discipline, like the international order, has a pre and post-I945 history. In the early, liberal period, discipline was not institutionalized, and in Europe the ways and means of studying international relations were discussed (Zimerman I939). After I945, Europe and France are torn apart and will no longer lead the political and scientific institutionalization of the new international order.

The professionalization of the PS study in France is already emerging in the new US-led order. The APSA will encourage the birth of national European associations and the birth of the International Political Science Association (IPSA). ISPA was founded in Paris in I949 and was attended by Raymond Aron. The French Association of Political Science is also born in I949.

Despite the French connection to the American Realists and the Rockefeller Foundation (Guilhot 2OI7b), IR began to develop in the US at a different pace and course than in France. This gave rise to the fact that, II years before Stanley Hofman, a Frenchman launches the question: "L'Étude des relations internationales, specialité americaine?” (Grosser I956).

Thus, unlike the Anglo-American world, the first relevant works of the French IR appeared only in the sixties, namely Aron's Paix et Guerre (I962) and Renouvin and Duroselle's Introduction à l'Histoire des Relations Internationales (I964).

However, we can say that there has always been a French IR school, with particular emphasis on its historic school led by Renouvin and Duroselle. This school combines the comparative-conceptual longue durée influence of the École des Annales with the evenentiale tradition of diplomatic history. Here, Braudel's work, namely his four main axes of inquiry into historical structures - time, space, social orders, and hierarchy - originated pioneering work on the understanding of civilizations and the historical evolution of societies and capitalism towards economic globalization. This approach was striking in the French school of the humanities and social sciences, to which French IR was not immune either. The famous "deep forces" (Renouvin, Duroselle I99I) and the attempt to construct a history-based IR theory (Duroselle, I992; I952) are one of the best examples of this influence.

Subsequently, a more sociological approach emerged that advocated overcoming the empirical view and the need for a theoretical-problematic perspective (Merle 1982, I986). This perspective advocated the possibility of reconciling the concepts of the American school with the developments of French political sociology. Although always with encyclopedic resistances and specificities, the French sociological school has been affirmed to this day (Smouths I987; Badie and Smouths I992). 
In addition to France there is a French-speaking academic community - starting with Switzerland, passing through Belgium and arriving in Quebec ${ }^{27}$ - which have dedicated themselves to IR. Following the French tradition, as a rule, they approach IR in a perspective of international studies and multidisciplinary interconnection with the traditional Sciences Politiques (History, Sociology, Philosophy, International Law, Economics) (Chillaud 2009). This has always meant a subordination of IR to traditional and dominant social sciences in the French university world, posing corporate-institutional obstacles to their academic self-determination. These French characteristics are also present in the foundation of the discipline in Portugal (Mendes 20I4).

On the other hand, the language issue was important in the Anglo-American domain in the discipline. Despite good transatlantic relations between the intellectual elites of the discipline, in the early years the generality of the North American academic community - especially students - read little French and the French, in turn, also read little English. This helped the non-development of French IR and the hegemony of the English language. Except of Aron, which has been translated into English, the French-speaking community has never been recognized as part of the IR academic community by the Anglo-Saxon world. It also demonstrates that often important and theoretically relevant work for IR progress is simply lost without translation.

France still doesn't have a Journal on the JCR WOS IR index today. In the index for PS, there is not the AFSP-sponsored journal, the Revue Francaise de Science Politique, but the oldest and interdisciplinary Revue d'Économie Politique (1887), reflecting, moreover, the historical tradition of political economy as a precursor of Political Science ${ }^{28}$.

Another feature of the French IR is their Parisian macrocephaly, reflecting the French sociological and political reality. All major IR study centers are concentrated in Paris. Here we can highlight the Center d'études des relations internationales (CERI), founded in 1952 at the Sciences Po by historian Jean-Baptiste Duroselle. Never changing its acronym, in 1976 it became Center d'études et de recherches internationales and in 2015 it becomes the current Center de recherches internationales.

At the University of Paris I (Panthéon-Sorbonne), the department of po-

27 Since I970, the University of Laval has edited Études Internationales Journal, an important publication in the French-speaking world.

28 The main French IR Journals are Critique Internationale, Cultures \& Conflicts, Politique Étrangère, Revue Francaise de Science Politique, Relations Internationales and Revue Internationale et Strategiques, among others. In France there is a French indexation that is composed of 9I "Sciences Politiques" journals, Available at: https://www.cairn.info/listerev. php? editeur $=\&$ discipline $=$ IO 
litical studies was founded in I969, and included Maurice Duverger, Madeleine Grawitz, Leo Hamon and Marcel Merle. From I977 onwards, an IR specialization emerged in the Master of Science Politique. In I979 the Institut français des relations internationales (IFRI) was created, which then started publishing the oldest French Journal of IR, founded in I936 within the CEPE, Politique Étrangère. This Journal is a perfect example of the early parochialism of the French IR. Although it is an old and quality Journal, it is essentially non-theoretical and based on empirical-descriptive objectives, having no international circulation outside the francophone world.

Indeed, French IR did not participate in the main debates that invented and socially constructed the IR discipline (Friedrichs 200I). However, in the transition of the century, French IR followed the global movement of IR affirmation. At the same time, the IR discipline has rediscovered the importance of French sociology (Jackson 2008; Bigo 20II; Adler-Nissen 20I2) and several French authors have come to be recognized globally. The greatest example is that of Bertrand Badie. Several of his latest works have been translated and he is the only French to be entitled to a Theory Talk ${ }^{29}$. Other French-born scholars have been able to make their mark in current IR, notably Didier Bigo co-founder and editor of International Political Sociology, Vincent Pouliot (2008) and Nicolas Guillot. These authors are examples of theoretical integration into the Anglo-American world of discipline. This means that there is a tendency for the emergence of some French authors and consequent internationalization in the center. However, as a rule, there remains in France an emancipatory view of the French IR against US rule. This view, by the way, seems to gain strength with the French's attempt to ally with the current global and counter-hegemonic movement of peripheral IR (Balzacq, Cornut, and Ramel, 20I7).

\section{The case of Germany}

Due to the historical circumstances that led to the instability and emergence of Nazism in Germany, in the foundational and formative years of the discipline (I9I9-I980) the important Germanic academic world took no particular prominence. As Czempiel, one of the deans of the German IR, has captured, the discipline in Germany was generally underdeveloped, as it was not in line with the theoretical debates and the respective scientific reference standards of the discipline - read the Anglo-American world. -sonic (Humrich 2006).

However, some German authors underline Germany's role in the origin

29 Available at http://www.theory-talks.org/20I7/07/07/theory-talk-74.html. Accessed March 8,2018 . As well as a chapter in Neumann and Waever (2005). 
of Continental IR. Here are pointed out various historical landmarks that can be interpreted as inspiring sources of the birth of discipline in Europe, for example: the German Peace Society (I892), the Colonial Institute of Hamburg (I908) or the Institut fur Auswartige Politik in Hamburg (I923) (Humrich 2006). Strictly speaking, apart from the aforementioned British experience, we can consider that the foundational mark of the discipline in its continental European vision took place in 1939 in Prague. An international conference sponsored by the Society of Nations (SDN) was held here, where attempts were made to discuss the principles of an IR discipline (Jørgensen, Knudsen 2006, I). However, like SDN, this conference did not have the expected results and its objectives were shattered with the outbreak of World War II.

Although the Deutsche Vereinigung für Politikwissenschaft (DVPW), the German Political Science Association, was founded in I95I, and had an important relationship with IPSA, IR was not one of its priorities. This circumstance is also related to Germany's difficult role in the new international order, divided, dependent and limited by Westbindung and Halstein doctrine. After Ostpolitick and the start of détente, Germany gained greater autonomy in its foreign policy which was also reflected in the need to develop its IR.

Thus, we can situate the beginning of the institutionalization of German IR from the mid-sixties. However, the affirmative emergence of the discipline occurs in the nineties, namely with the foundation in I994 of the Zeitschrift für Internationale Beziehungen (ZIB) (Journal of International Relations). The ZIB sponsored important debates about what German IR were and should be. For example, the debates surrounding its connection to the Frankfurt school and the influence of Habermas; its relation to rationalist institutionalism as well as constructivism. These debates have resulted in important post-critical, institutionalist, and constructivist syntheses in the scientific production of German IR (Jørgensen, Knudsen 2006).

However, the major debate in German IR was about whether IR theorizing ability was dependent on or independent of the Anglo-American center. It was here that the discussion began about home-grown versus imported theorizing. It was at ZIB that Günther Hellmann and Michael Zürn debated the German IR theoretical deficit and its theoretical dependence on the US (Hellmann 1994; Zürn 1994). All agreed on the diagnosis of the need for German IR to solidify and surpass their theoretical underdevelopment. The fundamental question was: how to overcome it?

Helman argued that German IR should follow US theoretical leadership and develop strategies for integrating German IR into US academic debates and forums. In contrast, Zurn advocated a strategy for German IR resilience, a third way between Americanization and German parochialism. Zurn came up 
with an interesting metaphor to explain the relationship between the American center and the German IR semi-periphery. In his view, the German rabbit would like to run, but does not do so because he is mesmerized by the American snake (Zurn I944, IIO-III). What Zurn argues is that German IR, instead of developing with their own agenda and theories, risked, through a paralyzing fascination, to be reactively dependent on the agendas of American inquiry.

With the end of the Cold War and reunification, Germany became an important and attractive center for IR study, with its traditional universities not immune to the globalization of discipline and playing an important role in continental rediscovery of International Relations.

It is not possible to perceive the constructivist (re) invention of discipline at the turn of the century without the contribution of German authors. Important authors of German origin, such as Thomas Risse, Thomas Diez, Mathias Albert, Rittenberg, or Michael Zurn, have marked the contemporary IR theoretical agenda and contributed to the erosion of the hegemonic transatlantic division of discipline, notably with a strong participation in the EJIR, the best and most paradigmatic framework for the European affirmation of the discipline (Mendes, 20I2).

From an institutional point of view, there is currently an important German IR community. Most German universities offer IR study cycles. Although it is possible to identify a particular theoretical-philosophical bias in the German authors, there is still no German identity of IR, as in law or philosophy. Unlike the Nordic case, there is also no Journal of relevant German international circulation $^{30}$. However, the German strategy seems to have followed a model of solidification from the outside through internationalization. German academics mimic two tendencies of Central American discipline: on the one hand the rise of the constructivist paradigm and, on the other, non-paradigmatic empirical inquiry (Wemheuer-Vogelaar, Risse, Thomas 2018).

German IR assert themselves and constitute one of the added value of the discipline at both European and global level, read Anglo-American. Its scholars have integrated into the major Anglo-American and European IR circuits and are present in leading journals of the discipline as authors and editors. This means that German IR did not solidify themselves only through Germanization, as Zurn argued, but rather through a simultaneous process of European and American internationalization.

30 ZIB continues to be published in German. In English there is German Politics, which is interdisciplinary. There are, however, major journals of area studies, notably Asian (for example: Journal of Current Chinese Affairs and Journal of Current Southeast Asian Affairs) and African (for example: Afrika Spectrum). 
Examples of this integration are the contributions of Helman and Zurn to the theoretical discourse of the discipline. Either through the possibility of dialogues and theoretical syntheses (Helman 2003); assumption of the importance of pragmatism for IR progress (Helman 2009; or through transnational methodological systematization (Helman 20I4). Another important mark of German IR is its sophisticated sociological culture. This culture has contributed decisively to greater sociological concern in the IR study (Albert, Buzan and Zürn, 20I3).

Fig. 1. Relationship of theoretical and institutional integration between the various academic communities and the Anglo-American center

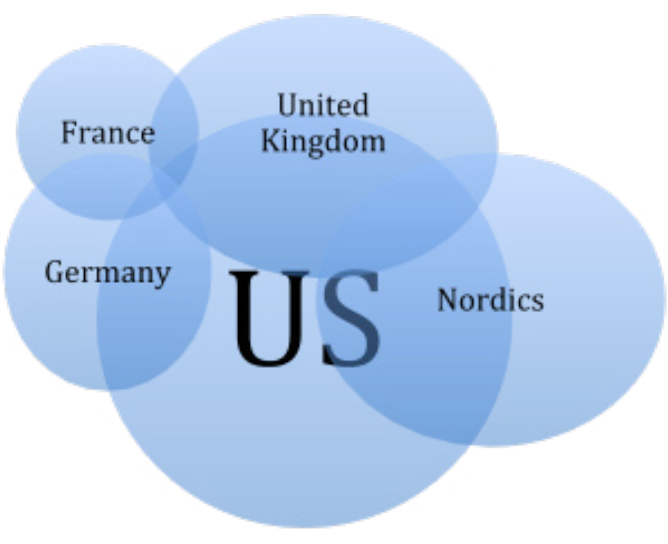

Source: The Author

Table 6. Characterization of the differentiation versus theoretical integration against the Anglo-American center $(0-5)^{31}$

\begin{tabular}{|cc|cr|cr|}
\hline \multicolumn{2}{|l|}{ internationalization } & \multicolumn{2}{|l|}{ theoretical differentiation } & theoretical integration & \\
\hline IR english & 5 & IR english & 3 & IR english & 5 \\
\hline IR nordic & 5 & IR nordic & 3 & IR nordic & 5 \\
\hline IR french & 2 & IR french & 4 & IR french & 2 \\
\hline IR german & 4 & IR german & 2 & IR german & 4 \\
\hline
\end{tabular}

3I O nonexistent; I very weak; 2 weak; 3 reasonable; 4 strong; 5 very strong. 


\section{Final Remarks}

IR was a discipline invented and dominated by the Anglo-American world, especially the American school. Although their intellectual roots are European, IR has become autonomous in the Anglo-American world for historical, ideological and institutional reasons. While Europe experienced the destruction of war, in the USA there were material and ideational conditions that provided the consolidation of the study of political science and policy sciences. Then the US leadership in building the new postwar liberal order drove the need for useful knowledge of international politics (Mendes 2020).

Interconnectedly, progressive liberal ideas and principles were particularly influential in the new American world, namely the idea that for every problem there is always a solution. This rationalism, enabling and progressive, originated the institutional development of departments and university schools of political studies and international relations. In its origin, Political Science is national and studies national public policies. Precisely when the United States becomes international leaders, by political obligation and scientific necessity, it turns the study of international politics into a public policy of national interest.

In addition to the US, there are two well-established IR schools with unique epistemological identities and an interesting theoretical capacity to think outside the box: the UK and the Nordics. Both developed with strong relations with the center but at the same time could develop their own theoretical discourse. The United Kingdom gave rise to the English School and International Political Theory. The Nordic School to "peace studies" and a more sociological and less neo-economic view of the FPA.

Regarding the Continental European Schools analyzed, it is important to underline the different institutional and theoretical paths of France and Germany vis-à-vis the Anglo-American center. IR in France was born with the mark of its historical school, later developed a more sociological approach. However, they did not establish relations of theoretical integration with the Anglo-American center. IR in France was a subfield of History and Political Science, with empirical, policy-oriented concerns and few theoretical concerns. The French IR adopted a strategy of resilience and autonomy in the face of the theoretical and institutional models of the construction of discipline in the Anglo-American world. In France, IR has developed a relatively parallel and exclusively Francophone vision. This parish vision lasted until the 2Ist century. Although France has followed the global diffusion of international studies, this has not erased the historical, encyclopedic, sociological and intellectual culture from the French view of the study of IR.

Unlike France, Germany has not developed a resilient and parochial 
attitude of its IR community towards the Anglo-American center. Paradoxically, in the early years of the invention of discipline, French IR had a greater disciplinary tradition than in Germany. In comparative terms, this relative French institutional and autonomic superiority remained post-war until the late I980s. This situation began to reverse in the nineties. From here, the German IR made a big leap, both qualitative and quantitative, to establish themselves as one of the strongest communities in Continental Europe and to participate in the agendas and theoretical discussions of the Anglo-American center of the discipline. This evolution took place through a simultaneous process of Europeanization and Americanization of German IR.

This article demonstrates five evidences in the development of the discipline. First, IR has a strong relationship with international relations. The discipline is born as a result of historical and political impacts and has a deeply practical genesis and connection to the world of public decision-making. IR result from the need for the production of useful knowledge for political decision making, namely for the foreign policy of states and the construction and organization of the architecture of the international order.

Second, IR develops more easily in democratic regimes and with an important international insertion, notably with active extraregional foreign policies and hegemonic or imperial traditions, as underlined by the "Pasquino-Hoffmann law" (Friedrichs 2001).

Third, the more solidified academic communities demonstrate a close relationship with the center's debates and agendas, but at the same time assume a theoretical-identity differentiation.

Fourth, despite the geo-cultural diversity and growing global affirmation of the discipline, the Anglo-American world and especially the US continue to dominate the discipline both quantitatively and qualitatively.

Fifth, despite the continuity of this domain, Europe has established itself as the second most important scientific community for IR. The quantitative, and above all qualitative, distance from the US is drastically reduced. This has been the result of strategies for the modernization and solidification of European national schools and their Europeanization. This Europeanization of the discipline resulted from the growing regional collaboration between leading academic and professional institutions, highlighting the role of ECPR and EJIR Journal. This Europeanization of the discipline culminated in the creation of the European International Studies Association (ESSA) in 2014.

Sixth, and lastly, the end of the cold war in the political world and the end of paradigmatic wars in the academic world influenced the solidification and global spread of the discipline. The acceleration of globalization has prompted 
renewed interest in international studies. IR is no longer perceived only as a specialization of American Political Science.

\section{REFERENCES}

Acharya, Amitav. 20I4. "Global International Relations (IR) and Regional Worlds: A New Agenda for International Studies.” International Studies Quarterly 58, (4): 647-659.

Adler-Nissen, R. ed. 20I2. Bourdieu in international relations: Rethinking key concepts. London: Routledge.

Albert, M. e Buzan, B. e Zürn, M. eds. 20I3. Bringing Sociology to International Relations: World Politics as Differentiation Theory. Cambridge: Cambridge University Press.

Almond, Gabriel A. I998. "Political Science: The History of the Discipline." In The New Handbook of Political Science, edited by Goodwin, R. E.; Klingemann, H., 50-96. Oxford/ NY: Oxford University Press.

Apunen, O. I993. “'Eurodiscipline’ wanted? International Relations as a research orientation and academic discipline in Europe." In International Relations and Pan-Europe: Theoretical Approaches and Empirical Findings, edited by F.R. Pfetsch, I-I7. Hamburg: Lit Verlag

Badie, Bertrand e Marie-Claude Smouts. I992. Le Retournement du Monde: Sociologie de la scène internationale. Paris: Presses de la Fondation Nationale de Sciences Politiques and Dalloz.

Balzacq, T., Cornut, J. e Ramel, F. 20I7. "Les Global International Relations comme alternative à la discipline hégémonique. Le cas des Relations internationales en France. Critique international." 74(I):69-93.

Bauer, H. e Brighi, E. ed. 2003. International relations at LSE: A history of 75 years. London: Millennium Publishing Group,

Biersteker, Thomas J. 2009. "The Parochialism of Hegemony: Challenges for "American" International Relations." In International Relations Scholarship around the World, edited by Arlene B. Tickner e Ole Wæver. New York: Routledge.

Bigo, D. 20Iı. "Pierre Bourdieu and international relations: Power of practices, practices of power." International Political Sociology 5 (3): 225-258.

Boncourt, Thibaud. 2009. A History of the International Political Science Association 1949-2009. Montreal: The International Political Science As- 
sociation,

Breuning, M., Bredehoft, J., Walton, E. 2005. "Promise and Performance: An Evaluation of Journals in International Relation." International Studies Perspectives 6 (4): 447-46I.

Brown, C. 2000. "International political theory: a British social science?" British Journal of Politics and International Relations 2 (I):II4-I23,

Browning, C. S. 2007. "Branding Nordicity: Models, Identity and the Decline of Exceptionalism." Cooperation and Conflict 42 (I): 27-5I.

Buzan, B. 200I. "The English School: An Underexploited Resource in IR." Review of International Studies 27( 3): 47I- 88.

Buzan, B. 2004. From International to World Society? The English School Theory and the Social Structure of Globalisation. Cambridge: Cambridge UP,

Carlsnaes, W. I993. "On Analysing the Dynamics of Foreign Policy Change: A Critique and Reconceptualization." Cooperation and Conflict 28:5-30.

Carlsnaes, W. I994. "In lieu of a Conclusion: Compatibility and the Agency-Structure Issue." In Foreign Policy Analysis. European Foreign Policy: The EC and Changing Perspectives in Europe edited by W. Carlsnaes and S. Smith, 274-

Carvalho, B. e Leira, H. e Hobson, J. 20II. "The myths that your teachers still tell you about I648 and I9I9." Millennium: Journal of International Studies 39(3): 735-758.

Cervo, Amado. 2008. Inserção Internacional. Formação dos conceitos brasileiros. São Paulo: Editora Saraiva,

Chillaud, Matthieu. 2009. "International Relations in France: The "Usual Suspects" in a French Scientific Field of Study?" European Political Science 8: 239-253.

Dunne, T. I998. Inventing International Society: A History of the English School. Basingstoke: Macmillan.

Duroselle, Jean-Baptiste. I952. "L'Étude des Relations Internationales: Objet, Méthode, Perspectives." Revue Française de Science Politique 3(2): 676701 .

Duroselle, Jean-Baptiste. I992. Tout Empire Périra: Théorie des Relations Internationales. Paris: Armand Colin.

Friedrichs, J. 200I. "International Relations Theory in France." Journal of International Relations and Development 4 (2): II8-I37.

Friedrichs, J. 2004. A House With Many Mansions: European Approaches to International Relations Theory. London: Routledge. 
Friedrichs, J. 2006. “The Nordic countries.” In International Relations in Europe, edited by Jørgensen K. e Knudsen, T., I25-I47. London: Routledge.

Giesen, Klaus-Gerd. 2006. "France and other Frenchspeaking countries (I945-I994)." In International Relations in Europe: Traditions, Perspectives and Destinations edited by 19-46. London: Routledge.

Giles, M. W., Garand, J. C. 2007. "Ranking Political Science Journals: Reputational and Citational Approaches." PS: Political Science and Politics 40:74I-75I.

Grosser, Alfred. I956. "L'étude des relations internationales, spécialité Americaine?” Revue Française de Science Politique 6 (3):634-5I.

Guilhot, N. 2008. "The Realist Gambit: Postwar American Political Science and the Birth of IR Theory." International Political Sociology 4 (2): 28I304 .

Guilhot, Nicolas. 20II. The Invention of International Relations Theory: Realism, the Rockefeller Foundation, and the 1954 Conference on Theory. New York: Columbia University Press.

Guilhot, Nicolas. 20I7a. “'The French Connection'. Éléments pour une histoire des relations internationales en France.” Revue française de science politique I $(67): 43-67$.

Guilhot, Nicolas. 20I7b. After the Enlightenment. Political Realism and International Relations in the Mid-2oth Century. Cambridge: Cambridge University Press.

Gustavsson, J. I999. "How Should We Study Foreign Policy Change?” Cooperation and Conflict 34 (I): 73-95.

Hellmann, G. (I994). "Für eine problemorientierte Grundlagenforschung: Kritik und Perspektiven der Disziplin "Internationale Beziehungen" in Deutschland", Zeitschrift Für Internationale Beziehungen I (I): 6590.

Hellmann, G. 2009. "Pragmatism in International Relations." International Studies Review II(3): 638 -662.

Hellmann, G. 20I4. "Methodological Transnationalism-Europe's Offering to Global IR?” European Review of International Studies, I (I): 25-37.

Hellmann, G. ed. 2003. "Symposium: Dialogue and synthesis in individual scholarship and collective inquiry." International Studies Review 5(I): I23-I5O.

Hobson, J. M. 2012. The Eurocentric conception of world politics: Western international theory, 1760-2010. New York: Cambridge University Press. 
Hoffmann, S. I977. "An American Social Science: International Relations." Daedalus I06: 4I- 60.

Holsti, K. J. I985. The Dividing Discipline: Hegemony and Diversity in International Theory. Winchester: Allen \& Unwin .

Humrich, C. 2006. "Germany." In International Relations in Europe, edited by Jørgensen K. e Knudsen, T., 72-98. London: Routledge.

Jackson, P. 2008. "Pierre Bourdieu, the "Cultural Turn" and the Practice of International History." Review of International Studies 34 (I): 155-8I.

Jönsson, C. I993. "International Politics: Scandinavian Identity amidst American Hegemony?” Scandinavian Political Studies I6 (2): I49-65.

Jørgensen, K. e Knudsen, T. ed. 2006. International Relations in Europe: Traditions, Perspectives and Destinations. London: Routledge.

Jørgensen, K. E. 20I5. "Discursively (de-)constructing European foreign policy: Theoretical and methodological challenges." Cooperation and Conflict 50(4):492-509.

Jørgensen, K. E. e Aarstad, A. K. e Drieskens, E. e Laatikainen, K. e E Tonra, B. eds. (20I5), The SAGE handbook of European foreign policy. London, SAGE.

Jørgensen, Knudsen 2006. "Introduction." In International Relations in Europe, edited by Jørgensen K. e Knudsen, T., I-I6. London: Routledge.

Kahler, M. I997. "Inventing International Relations: International Relations Theory after I945." In New Thinking in International Relations Theory, edited by Doyle M. and Ikenberry, J., 20-53. Boulder: Westview Press.

Kristensen Peter M. 20I3. "Revisiting the "American Social Science"- Mapping the Geography of International Relations." International Studies Perspectives I-24.

Lake, D. 20II. "Why 'isms' are evil: Theory, epistemology, and academic sects as impediments to understanding and progress." International Studies Quarterly 55(2): 465-480.

Larsen, H. 2009. "A Distinct FPA for Europe? Toward a Comprehensive Framework for Analysing the Foreign Policy of EU Member States." European Journal of International Relations I5 (3): 537-566.

Lawson, G. 20I4. "Rethinking benchmark dates in international relations." European Journal of International Relations 20(2): 437-462.

Linklater, Andrew; Suganami, Hidemi. 2006. The English School of International Relations: a contemporary reassessment. Cambridge: Cambridge University Press. 
Maliniak, Daniel e Peterson, Susan e Powers, Ryan e Tierney, M. J. 20I8. “Is International Relations a Global Discipline? Hegemony, Insularity, and Diversity in the Field." Security Studies 27(3): 448-484.

Maliniak, Daniel, Susan Peterson, Ryan Powers, Michael J. Tierney. 2012. TRIP Around The World: Teaching, Research, and Policy Views of International Relations Faculty in 20 Countries. Williamsburg, VA: Institute for the Theory and Practice of International Relations.

Maliniak, Daniel, Susan Peterson, Ryan Powers, Michael J. Tierney. 2014. TRIP 2014 Faculty Survey Report. Williamsburg, VA: Institute for the Theory and Practice of International Relations. https://trip.wm.edu/reports/20I4/rp_20I4/.

Mellander, M. e Mouritzen, H. 2016. "Learning to assert themselves: Small states in asymmetrical dyads-two Scandinavian dogs barking at the Russian bear." Cooperation and Conflict 5I(4): 447-466.

Mendes, P. E. 20I2. "A (re) invenção das Relações Internacionais na viragem do século: o desafio do construtivismo". Relações Internacionais, no 36 , IPRI-UNL, pp. I05-II8.

Mendes, P. E. 20I4. “As relações internacionais como ciência social: dialética entre história e teoria”. In F. Sousa e P. Mendes (eds.), Dicionário das Relações Internacionais, Porto, Afrontamento, pp. xvi-xxxvi.

Mendes, P.E. 20ı9. "As teorias principais das Relações Internacionais: uma avaliação do progresso da disciplina”. Relações Internacionais, no 6I, pp. 95-122.

Mendes, P.E. 2020. "R(r)elações I(i)nternacionais, Realismo e Análise da Política Externa (APE): contextualizando a invenção da APE”. Estudos Internacionais, (in press).

Merle, Marcel. I986. Les Acteurs dans les Relations Internationales. Paris: Economica.

Merle, Marcel. I982. Sociologie des Relations Internationales. Paris: Dalloz.

Morgenthau, Hans J. I948. Politics Among Nations: The Struggle for Power and Peace. New York: Knopf.

Neumann, Iver B. e Wæver, Ole. 2005. The Future of International Relations Masters in the Making? London. Routledge.

Olson, William e Groom, A.J.R. I99I. International relations then and now: Origins and trends in interpretation. London: Harper Collins,

Olson, William, and Onuf, Nicholas. I985. "The Growth of a Discipline: Reviewed." In International Relations: British and American Perspectives, edited by Steve Smith. Oxford: Basil Blackwell. 
Pouliot, V. 2008. "The logic of practicality: a theory of practice of security communities." International Organization 62 (2): 257-288.

Renouvin, Pierre e Jean-Baptiste Duroselle. I991. Introduction à l'histoire des relations internationales. Paris: Armand Colin.

Schmidt, B. 20I3. "On the history and historiography of International Relations." In Handbook of International Relations, edited by Carlsnaes W., Risse, T; Simmons, BA, 3-28. Thousand Oaks: SAGE.

Schmidt, B.C. I998. The Political Discourse of Anarchy: A Disciplinary History of International Relations. Albany: State University of New York Press.

Schmidt, B.C. 2008. "Political Science and the American Empire: A Disciplinary History of the 'Politics' Section and the Discourse of Imperialism and Colonialism." International Politics 45 (6): 675-87.

Schmidt, Brian C. e Guilhot, Nicolas. eds. 20I9. Historiographical Investigations in International Relations. London: Palgrave Macmillan.

Smith, S. I995. "The self-image of a discipline: A genealogy of international relations theory." In International relations theory today edited by K. Booth e S. Smith,I-37. Cambridge: Polity.

Smouts, Marie-Claude. 1987. "The Study of International Relations in France", Millennium. Journal of International Studies I6 (2): 28I-286.

Vigezzi, Brunello. 2005. The British Committee on the Theory of International Politics (1954-1985): The Rediscovery of History. Milano: Edizioni Unicopli.

Villa, Rafael A. e Pimenta, Marilia S. 20I7 "Is International Relations still an American social science discipline in Latin America?" Opinião Pública 23(I):26I-288.

Vitalis, R. 2005. "Birth of a Discipline". In Imperialism and Internationalism in the Discipline of International Relations edited by D. Long e B. Schmidt, I59-8I. Albany: State University of New York Press.

Wæver, O. I998. "The Sociology of a Not So International Discipline: American and European Developments in International Relations." International Organization 52(4): 687-727.

Wæver, O. 20I3. "Still a discipline after all these debates?" In International relations theories: Discipline and diversity edited by T. Dunne e M. Kurki, e S. Smith, (2d ed.) 306-328. Oxford: Oxford University Press.

Wæver, O. e Tickner, A. B. 2009. "Introduction: Geocultural epistemologies." In International Relations Scholarship Around The World, edited by A. B. Tickner e O. Wæver. London: Routledge.

Waever, Ole. I994. "Resisting the Temptation of Post Foreign Policy Analy- 
sis." In European Foreign Policy. The Changing Perspective in Europe, edited by Carlsnaes, Walter and Smith, Steve, 238-273. London: SAGE.

Wemheuer-Vogelaar, Wiebke e Bell, N. J. e Morales, M. N., Michael J. e Tierney, M. J. 20I6. "The IR of the Beholder: Examining Global IR Using the 20I4 TRIP Survey." International Studies Review I8 (I) I:6-32.

Wemheuer-Vogelaar, Wiebke e Risse, Thomas (20I8) “International Relations Scholars in Germany: Young, Internationalised, and Non-Paradigmatic." German Politics 27( I): 89-II2.

Wheeler, N. 1992. "Pluralist or Solidarist Conceptions of International Society." Millennium 2I (3): 463-87.

Wight, M. I99I. International Theory: The Three Traditions, ed. G. Wight and B. Porter. Leicester: Leicester University Press.

Zimmern, A. ed. I939. L'Ensignement Universitaire des Relations Internationales. Paris: Institut International de Cooperation Intellectuelle.

Zürn, M. I994. "We Can Do Much Better! Aber muss es auf Amerikanisch sein? Zum Vergleich der Disziplin "Internationale Beziehungen" in den USA und in Deutschland." Zeitschrift für Internationale Beziehungen I (2): 9I-II4.

\section{ABSTRACT}

This article provides a contextualization of the invention of International Relations (IR) in the Anglo-American world and Continental Europe. It presents a historiographic synthesis of the main institutional and scientific landmarks of the American, English, Nordic, French and German cases. It begins by presenting the main contexts and political-academic frameworks of the birth and formation of the discipline, with an emphasis on the USA. Secondly, it addresses the European developments of the IR discipline, highlighting the English and Nordic schools. Finally, it presents a brief contextualization of the rediscovery and affirmation of IR in Continental Europe, identifying the main institutional and scientific milestones of the French and German schools.

\section{KEYWORDS}

Birth of the discipline of International Relations; American School of International Relations; European Schools of International Relations.

Received on December 17, 2018

Approved on August 18, 2019

Translated by Eduardo Secchi 